\title{
RECONCEIVING PATENTS IN THE AGE OF VENTURE CAPITAL1
}

\author{
Prof. Mark Lemley2 \\ for the 1999 Lewis \& Clark Law Forum \\ October 1, 1999 \\ Portland, Oregon
}

I call this talk "Reconceiving Patents in the Age of Venture Capital" but it might also be called "A Curiously Optimistic Vision of the Patent System." I say curiously optimistic because after you hear the first half of my talk, you'll wonder what could possibly be optimistic about it. I hope to answer that in the second half of the talk.

\section{A. The Growth of Patents}

It's no surprise to anybody, I think, that patents are big business. This is a relatively recent development. Patents are in the news. It's one of the delightful things about teaching in this area that things we're interested in actually turn out to capture the public imagination. They show up on the front page of the New York Times. More to the point, patents are a growth industry. The U.S. Patent and Trademark Office issued over 160,000 patents last year.3 That's up 50\% over the number two years before. The rate of increase shows no sign of slowing, and it is a radical break from the kind of gradual increase that had preceded it. 4

1 (C) 1999 Mark A. Lemley.

2 Marrs McLean Professor, University of Texas School of Law; of counsel, Fish \& Richardson P.C. Effective January 1, 2000, Professor Lemley will be Professor, Boalt Hall School of Law, University of California at Berkeley.

3 U.S. PTO statistics indicate that they issued 163,209 patents in 1998, up from 124,146 in 1997. See PTO Patents Up in 1998, 57 Patent, Trademark \& Copyright J. (BNA) 347 (Feb. 25, 1999).

4 For recent data in representative years through 1995, found in the Additional Information section of the PTO's 1996 Annual Report, see http://www.uspto.gov/web/offices/com/annual (visited Nov. 21, 1997). Data for those representative years are: 
What this means if you multiply it out is that there are over 2 million patents now in force in the United States. If you do a little math and you know how much it actually costs to get a patent through the entire system, it's pretty easy to see that in the U.S. alone, the prosecution costs—what we're paying patent prosecutors and the PTO — exceeds $\$ 5$ billion a year, 5 to say nothing of costs in the rest of the world, the costs of litigation or, of course, any of the costs of licensing.

Finally, patent litigation is increasing dramatically. I want to give just one example here, which comes from the District of Delaware. The district judges there recently did a study of trends in civil litigation and what they found is that in their district, $13.5 \%$ of all new civil cases filed in the District of Delaware are patent litigation suits. $13.5 \%$. And that's of all civil cases in an important jurisdiction for civil litigation.

\section{B. The Problem}

\section{Understanding Innovation}

What's the problem? The problem is, quite frankly, that we don't have a clue how innovation works. That is not a surprise to economists. One famous economist at Yale told us that economic analysis of the patent system, the business that I' $m$ in, is “one of the least productive lines

\begin{tabular}{|c|c|c|c|c|}
\hline Year & US Pats & $\begin{array}{l}\text { Foreign } \\
\text { Pats }\end{array}$ & Total Pats & $\%$ Foreign \\
\hline 1983 & 32871 & 23989 & 56860 & $42.2 \%$ \\
\hline 1986 & 38126 & 32734 & 70860 & $46.2 \%$ \\
\hline 1989 & 50185 & 45354 & 95539 & $47.5 \%$ \\
\hline 1992 & 59760 & 49968 & 109728 & $45.5 \%$ \\
\hline 1995 & 64562 & 49679 & 114241 & $43.5 \%$ \\
\hline
\end{tabular}


of inquiry in all of economic thought."'6 The basic structure of the problem is this: the patent law model we have, or the understanding we have of why we engage in this process, is quite simple: We give you a patent; the patent gives you the right to exclude; you can use that right to exclude competitors in order to raise your price, and therefore make more money; and that fact in turn gives you an incentive to create. That is, we give you an exclusive right; the exclusive right gives you more money. The prospect of more money encourages you to go out and innovate. It's a very simple model. It's been the model for basically 200 years.

Innovation on the other hand, is very complex. We're not sure exactly what causes invention, but one of the things we do know is that it differs by industry: that what drives innovation in the pharmaceutical industry is very different than what drives it in the software industry, and very different again than what drives it in the semiconductor industry. We also know that it differs within industries by firm size: that the way large companies innovate is very different than the way that small start-ups or mid-size companies innovate. And we know that even controlling for size and industry, innovation differs from firm to firm. Different firms simply approach things in different ways, and you cannot take a model that worked in one firm and replicate it in another city or with another group of people and assume that the same model will work in the same way—no matter how many times you try to control the variables. Finally, there is simply a large degree of serendipity associated with invention by its very nature. Part of the problem is that we may never be able to know exactly what sparks a thought or a creative idea in somebody's mind.

6 See George Priest, What Economists Can Tell Lawyers About Intellectual Property, 8 Res. L. \& Econ. 19 (1986). 
If we don't know what causes innovation, how do we know patents promote innovation? Here, again, it seems to me that we've got some rather difficult problems. We don't, in fact, know for sure what impact patents have on innovation. This is not a new problem. Fritz Machlup in a 1958 study commissioned by the U.S. Congress came to the remarkable conclusion that if we didn't have a patent system, it would be irresponsible to create one, but since we have one, it would be irresponsible to eliminate it.7 Hardly, I think, a ringing endorsement of the patent model of innovation.

One of the things I want to suggest in this talk is that as we as a society invest more and more resources in patents, as we move down the road of getting more patents and more patent litigation, and as we come to depend more heavily on innovation, we've got to figure out what in fact the patent system has to do with innovation.

\section{Does the Patent System Threaten Innovation?}

To complicate matters further, there is some evidence that suggests that patents may actually inhibit innovation. I want to focus here just for a minute on John Barton's recent empirical work.8 He has a paper with some disturbing empirical conclusions. One of the things he finds is that patents granted per R\&D dollar are increasing, but that actual R\&D expenditure adjusted for inflation is going down. So we are increasing the number of patents, but not necessarily increasing the amount of money we invest in research and development.

7 See, e.g., Staff of Senate Subcomm. on Patents, Trademarks, and Copyrights, Senate Comm. on the Judiciary, 85th Cong., 2d Sess., An Economic Review of the Patent System: Study No. 15 at 76-79 (Comm. Print 1958) (prepared by Fritz Machlup).

8 John Barton, Reforming the Patent System (working paper 1999). 
Patent litigation, he finds, is clearly going up. When he correlates a lot of the variables -patent litigation, number of patents, research and development, and a number of others -- what he finds, curiously, is that the only figure strongly correlated to the number of patents and the number of patent lawsuits is the number of patent lawyers. The more patent prosecutors there are, the more patents get issued from the U.S. Patent and Trademark Office. Now I'm a patent lawyer, so that doesn't trouble me particularly as an individual, but perhaps it should give us pause as a society.

Other people have suggested that as we move away from the model of patents that existed in 1790 - that is, the individual innovator working in their garage - towards large corporate entities, the link between innovation and patent reward might be broken. Individuals who work for large corporations no longer see the particular incentive or reward coming out of their particular innovation. The reward goes to a corporation and is a somewhat more diffuse incentive. Corporations get revenues from patents, but the revenues don't necessarily go to the departments or the individuals who engage in innovation, and the incentive effect is therefore less.

Others have suggested that big companies patent, but small companies innovate. This is something that's true in some industries but not others. In particular, in the software industry, a number of people have argued that the companies that get patents are not the ones at the forefront of technological innovation. Rather, the people at the forefront of technological innovation are the ones working in garages who don't know any patent lawyers and therefore don't patent anything.

We've also seen the development of what I call "licensing shops," that is, significant corporate entities with little or no business purpose other than to accumulate and license patents. These companies are not engaged in the business of building products. They might be engaged in the 
business of thinking of ideas, but they seem mostly to have patents and therefore patent licensing documents as their output.

Finally, patents sometimes raise the barriers to new firm entry into a market. If you wanted to start a software company in 1970, you really did need only a garage and an old computer in order to do it. If you want to start a software company today, depending on the software submarket you're in, you may need a significant patent portfolio and licenses from a number of other companies that have a significant patent portfolio. Indeed, in some industries, this barrier to entry (or ante to the game) is so significant that a recent study found that if you wanted to enter the microprocessor field and you didn't have your own patents to bring to the cross-licensing pool, the amount of money you'd have to pay in patent licensing fees was $\$ 100,000,000.9$ That's just to get in the game, and has nothing to do with actually investing in production facilities or hiring engineers.

Finally, some empirical work that I've been involved in suggests that patent litigation doesn't generally involve what we think of as the most innovative industries. One of the problems is that patent litigation takes an awfully long time. Not only does it take time to resolve litigation once it's started, but most of the patents that are litigated are old patents to begin with. The average time from the filing of a patent application to the resolution of a lawsuit is 12.3 years. 10 There are a significant number of cases over the last ten years in which that period of time is over 20 years. The patents that actually get to court are patents that are based on technology that people thought of 15 or 20 years ago. Furthermore, our study found that most of the litigated patents are not in the areas of software,

9 See Weston Headley, Rapporteur's Report, http://stlr.stanford.edu/STLR/Symposia/Antitrust/99_VS_7/ (reporting the presentation of Michael Rostoker at the Stanford Workshop on Intellectual Property and Industry Competitive Standards, Stanford Law School, April 17-18, 1998.

10 John R. Allison \& Mark A. Lemley, Empirical Evidence on the Validity of Litigated Patents, 26 AIPLA Q.J. 185, 236 Table 11 (1998). 
biotechnology, or even computer hardware and pharmaceuticals. Most of them are mechanical patents. Most of them are what we might call low-tech devices-inventions, but inventions that we don't think of as the most innovative parts of our economy.11

Furthermore, patent plaintiffs often aren't themselves significant players in the industry. They may be the licensing shops I've talked about. They may be individuals who engage in what is called "paper patenting." -- that is, inventing something, but rather than building it themselves, going around and suing other people who do build it. Or they may be companies at the end of their useful technological life, that is, companies whose major asset is not new technology, but patents they got 10 or 15 years ago when they were in fact a more productive entity.

All of this leads me to ask the question, "is the patent system broken?" John Barton's paper starts with the presumption that the patent system is indeed broken.12 I'm not so sure. First, I don't think we have nearly enough evidence about how patents and innovation actually work. There is starting to be some empirical work in this area. There is starting to be some understanding of the relationship between patents and innovation since George Priest made his comment, but we clearly don't have nearly enough idea about the actual relationship between patents and innovation. At the least, though, it seems to me that we have enough, based on the evidence that I've given you, to question the classic incentive story. We should ask whether it's really true in the aggregate or in any particular case that people invent because they want the incentive that getting a patent will give them. We should also worry that patent litigation is as much about holding up innovation as it is about protecting it.

11 Id. at 217.

12 Barton, supra note _, at 1. 


\section{The Case of the Missing Patents}

So why in the world am I optimistic about the patent system? The answer has to do with the case of the missing patents. There are over 160,000 new patents issued every year. Where do they go? Well, some of them get litigated, but despite the dramatic increase in the numbers of litigation, we're talking there about maybe 1,000 to 2,000 lawsuits a year. We're talking about maybe one percent of all actual patents ever being litigated. So, the focus of the patent law system, which has been on patent litigation, is actually directed to only a tiny subset of those patents. There are other patents that get licensed in negotiated transactions but never go to litigation, of course. That increases the number beyond one percent, but at most it raises the number to two or three percent. We're still talking about only a tiny percentage of all patents.

So the overwhelming number of patentees are spending the money to go get patents, and then they're not enforcing them. Why? I want to suggest some possible reasons why, and some ways that we can reconceive the academic model of "patent as incentive" to take account of current realities.13

The first "new use" of patents has to do with cross-licensing in patent pools or standardsetting organizations. While some patent licensing is unilateral, a lot of patent licensing, particularly in fairly concentrated industries, takes the form of exchanges of patents. In effect, a patentee says: "Here is my stack of patents; there is your stack of patents. We'll trade." And often we'll trade on a no-cash basis. I'll let you use all of mine if you let me use all of yours. In the microprocessor industry example that I gave earlier, if you don't bring your stack of patents to the table, you'd better

13 While I suggest these as some "new" uses for patents, many of them are not in fact new -- those of you in practice will recognize a lot of these uses - but they're new to academic scholarship in the sense that they don't necessarily fit within our classic incentive model. 
bring cash, and you'd better bring $\$ 100,000,000.14$ But if you can bring a stack of patents to the table, you can use that as your entre into the system. 15

A second use is what I call "defensive use against litigants." One might also call this the patent arms race. A famous aphorism defines a lawyer as somebody whose primary job is to defend his client from other members of the profession. There's some truth to that in the patent system. One of the major reasons that companies go out and get patents is that they're afraid that their competitors have got patents, and they don't want to be the only one left who doesn't have the ability to play in this game. As patents enter new industries, we see this happen over and over again. Take software patents, for example. Twenty years ago few people were patenting software. Courts were still reluctant in many circumstances to grant software patents, and there were a whole lot of people in companies, even very large companies (Microsoft, for example, or Adobe Systems), who just didn't believe in the idea of software patents. They were opposed to the concept, and they were darned if they were going to go out and get software patents. But if somebody else has a patent and you don't have a patent, and they sue you, you have nothing to fight back with. And the companies that got sued and lost, like Microsoft — and even those who won, like Adobe — decided "never again. From now on, we're going to get patents just to stake out our territory, even if we have no intention of trying to license them to other people or trying to litigate with them." The same thing is happening in the business methods patent area, although it's less far along. Now that the courts have declared business ideas to be patentable subject matter, a number of companies who never would

14 Apparently the microprocessor industry doesn't take American Express.

15 For a discussion of these sorts of informal patent pools, see Robert P. Merges, Contracting Into Liability Rules: Intellectual Property Rights and Collective Rights Organizations, 84 Calif. L. Rev. 1293, 1354 (1996). 
have thought to do this, and have no intention of asserting the patents, still feel like they've got to get patents on their new business model as well.

Third, I think scholars have ignored the use of patents as financing tools. One of the things that prompted me to write this paper was sitting and listening to venture capitalists talk about what I call the love-hate relationship between VCs and patents. If you ask venture capitalists what they think of patents, and in particular, of patent litigation, they'll tell you it's awful. "This is a terrible thing; leave us alone and let us innovate," they will say. And then if you ask them how their companies are doing in the marketplace, they will answer you with reference to patents: "Our company has patented this model"; "our company got 12 patents this year"; "our company has patent applications that cover this, that and the other thing." Venture capitalists love patents in this form. But they don't really like it when patents actually get used. A recent study by Kortum and Lerner suggests that there is a strong positive relationship between venture capital financing and patenting. 16 This suggests to me in fact that one of the reasons people are patenting at a very early stage in the process is precisely in order to attract or appease venture capital. That is, they get patents in order to define their market model for their financiers.

Some other ideas:

- Some companies patent in order to have an idea registry. These companies are in essence recording their prior art. They invented something, so they patent it, in the same way that scientists might, in some other fields, go out and publish it. The company now has a

16 Samuel Kortum \& Josh Lerner, Does Venture Capital Spur Innovation? 1 (working paper 1998) ("we find that the amount of venture capital activity in an industry significantly increases its rate of patenting."). 
record: we invented this thing on this date, and the government gave us an official document with a seal on it that proves it.

- Sometimes patents are used simply as indicators of product differentiation or branding. A trivial example of this are companies that talk about "our patented method of doing X," or "our patented product on what-not." People use patents to differentiate themselves in product space from anybody else: "We are doing something a little bit different than all of our other competitors, and so that's why you ought to pay attention to us and not to them."

- I think there are some circumstances, particularly in academic settings, where patents turn out to be yardsticks for progress in research and development. One measure of output of research and development input is the number of patents granted. This is true not so much because of the intrinsic value of the patents themselves, but simply because a patent can be an end in itself to a scientist who will be rewarded for getting it or who wants to see it on their resume, or to a company who measures how innovative they are by how many patents they've got.

In short, what I'm suggesting is that we ought to change the focus of academic inquiry about the patent system away from the small number of cases that show up in court reporters, and towards these broader uses. We need to change our focus in thinking about patents and innovation. We ought to be focusing on how small and innovative companies perceive patents, if we really believe it's true that small and innovative companies are significant movers in actually coming up with new ideas. We ought to be asking how venture capitalists and the venture capital community see patents, what they think patents are useful for and what they don't think patents are useful for. And, we ought not 
to assume that the patentee is the only innovator in the equation. We should place patent law in the context of a broader innovation process that includes other parties as well.

\section{Implications for Patent Law}

If I'm right, what implications does this have for patent law? I'm going to suggest a number of possible conclusions, but I want to start out by cautioning you that all of this is speculation. The key implication is that we need to know more about these reasons for patenting in order to understand how the law should change. Still, I want to suggest a couple of possibilities if for no other reason than to be provocative.

\section{Do we encourage too much litigation?}

First, it seems to me that not only do we place too much emphasis in academic commentary on patent litigation, but we may actually encourage too much patent litigation. The best uses for patents may in fact be uses that don't involve litigating. As I said, a tiny percentage of all patents are litigated, although in many cases it's very important patents that are litigated. Litigation, because it takes so long, is rarely about exclusivity. If you've just come up with a new idea and a month later somebody tries to move into your product space, your best strategy is not to rush to the patent office, wait about two and a half years for them to give you a patent, 17 file your lawsuit, wait several more years to get a legal result.18 Usually, what is most at issue when a case actually goes to trial is money after the fact, not actually excluding a competitor. And the more quickly an industry changes, the more likely that is to be the case. Some industries may run through two, three, or even four

17 See Mark A. Lemley, An Empirical Study of the Twenty-Year Patent Term, 22 AIPLA Q.J. 369, 385 \& Table 1 (1994) (patents spend 864 days, or approximately $21 / 2$ years, in prosecution on average).

18 See supra notes 8-9 and accompanying text. 
product generations by the time we actually get finished litigating patent rights based on the first generation.

Furthermore, as I've indicated, patent plaintiffs may not be current innovators. They may be the paper patentees, the Jerome Lemelsons of the world, whose main "product" is the patent they own. They may be companies with old technology, Texas Instruments, for example, makes more money in the semiconductor space from licensing and litigating its patents, which are 15 to 20 years old, than it does actually selling products in that field (although it is quite innovative in other fields).

If we want to de-emphasize bad kinds of litigation, what might we do? Let me offer a couple of ideas. One is to get rid of the presumption of validity. There are a couple of reasons for this. First, I don't think, frankly, that patents deserve it. I've seen what happens in the U.S. PTO. The average amount of time that an examiner spends on a patent application in the U.S. PTO is something on the order of eight to ten hours. That includes reading the application, searching the prior art, reading the prior art, comparing the two, writing an office action and then, when the Examiner gets a response to the office action, doing it again and maybe doing it again and again and again. There is simply no evidence that a court should be bound by the outcome of this abbreviated proceeding. Now to some extent, in practice we may have eliminated the presumption of validity already. The study I did with John Allison found that $46 \%$ of all patents actually litigated are held invalid.19 Despite the presumption of validity, which is at least nominally a strong presumption, 20

19 See Allison \& Lemley, supra note _, at _..

20 Invalidity of a patent must be proven by clear and convincing evidence. See 35 U.S.C. § 282; Kahn v. General Motors Corp., 135 F.3d 1472, 1480 (Fed. Cir. 1998); Glaverbel Societe Anonyme v. Northlake Mktg. \& Supply, Inc., 45 F.3d 1550, 1555 (Fed. Cir. 1995). 
courts are invalidating just about as many patents as they are allowing when the case is finally resolved.

Second, perhaps we ought to think about limiting patent infringement to cases of copying rather than independent invention. This is, after all, what we do in copyright law. This idea obviously needs more examination. What we've got to do is figure out whether the kinds of patent litigation that cause the most problems are in fact cases involving people suing individuals they have no relationship with, individuals who independently invented the same idea. Then we should ask whether patent incentives would be substantially reduced if you could sue only people who copied from you.

Third, we might consider giving patent defendants a weapon with which to fight back. Patent defendants have already arrogated to themselves one particular weapon to fight back in patent litigation. That weapon is the antitrust counterclaim. If you do any kind of patent litigation, you will know that patent plaintiffs are virtually always met with an antitrust counterclaim. This weapon is not a particularly good one. Virtually none of those counterclaims are ever actually successful at trial. But what the patent defendant is looking for, I think, is some way to go on the offensive. Nobody wants to be on the defensive in litigation. One possible alternative we might consider is a partial fee-shifting idea: granting fees to patent defendants who prevail in some set of circumstances in which it looks like this case should never have been filed.

\section{Accelerating the patent process}

The second thing I want to suggest is that we need to bring patents closer to the innovative process, closer to what's actually going on in industry. One way to do this is to speed up the prosecution process. The best way I can think of to speed up the prosecution process is to hire lots 
more people in the patent office. We're going to have to hire more people anyway if we want to keep up with the pace of demand. If we also want to give more time to examination of each patent, we certainly have to hire more people. If we also want to get the patents out the door of the patent office earlier, which I think we should, then we've got to hire still more people to get rid of the backlog and process incoming files more quickly.

When we do have to have litigation, we ought to examine ways that we can make that litigation go more quickly. One of the nice things about patent litigation is you can file almost anywhere in the country. There are "rocket dockets" developing, but the judges in those rocket dockets often don't particularly like the idea that they're attracting patent litigation. Many of them don't particularly like patent cases. We need more rocket dockets in general in litigation in the United States. One way to try to do it in patent cases is to reward plaintiffs who are willing to settle for bench trials rather than jury trials. A court might say to a patent plaintiff, "Look, we'll get your case resolved quickly if you seek only injunctive relief or if you agree to a bench trial."

Finally, some people have suggested that just as we have a patent court of appeals, perhaps we ought to consider having a patent trial court. Those people tend to live in jurisdictions where judges don't particularly like patent cases, so they'll set your patent case for trial sometime in 2008 in the hopes that you'll settle.

\section{Encouraging private allocation of rights}

As I noted above, in many industries patents are not used to exclude competitors, but rather are traded in a more or less formal market for rights. While this market can sometimes be formal (as in the "patent pools" that characterized the early airline and auto industries), more often they are informal norms and business practices that characterize the dealings between repeat players in an 
industry. We can think of this as an example of the Coase theorem at work. The government grants an initial set of property rights, which may or may not be efficient from the perspective of actually producing goods. Private parties then ignore, allocate, or reshape those rights in the way that makes their lives easier. In so doing, they may ameliorate some of the more problematic features of patents, particularly their potential to hold up cumulative innovation.21

If we view the development of these informal rights-clearing organizations as a good thing (and I do), it follows that we should do what we can to encourage their formation. The single most obvious thing we can do is to restrict the application of antitrust law to patent pools and crosslicensing arrangements. While agreements between competitors are always suspect, most crosslicenses serve decidedly procompetitive goals, and they ought to be allowed.22

\section{Empirical research}

Finally, I think scholars need a much clearer idea than we currently have of how patents contribute - or don't contribute - to innovation. We need empirical data on how patents are actually used, how much patents cost society, and to the extent we can determine it, how much patents benefit society. And we need empirical work that focuses not just on litigation, not just on patent prosecution, but on the people on the ground: venture capitalists, small companies, and the people who are actually doing the innovating.

\section{Conclusion}

I think that the patent incentive story as classically told has some serious problems. But it does not follow from this that patents are a bad thing. In fact, patents serve a lot of useful purposes

21 See Merges, supra note _, at 1354.

22 Cf. Mark A. Lemley, Antitrust and the Internet Standardization Problem, 28 Conn. L. Rev. 1041 (1996) (making a similar suggestion). 
outside of that classic incentive story. If we focus on what patents actually do, rather than on what the law assumes that they do, we will be able to tailor the patent system the real needs of innovators. 